\title{
EFFECT OF REDUCED BEAM SECTION IN STAGGERED TRUSS FRAME STRUCTURE VIERENDEEL ELEMENT WITH EARTHQUAKE LOAD ANALYSIS
}

\author{
M. Farid Nurul Iman ${ }^{a}$, E. Wahyuni ${ }^{b}$, dan D. Iranatac
}

\begin{abstract}
The purpose of this study is to describe the effect of Reduced Beam Section in vierendeel panel element in STF system's inelastic behavior based on earthquake load analysis. STF system is applied to 4, 6, and 10 storey building that served as office building. The structure's system used Special Moment Resisting Frame (SMRF) system in longitudinal direction (W-E) and STF system in transversal direction (N-S). The analysis method that used in this study is nonlinear pushover analysis. Application of RBS in vierendeel panel element showed that by the increasing of storey number, the ductility of the structure was increased in both directions, while $N$-S direction has bigger ductility than W-E direction. Dissipation energy of the structure was also increased, especially in $N$-S direction. The first yielding process occurred in vierendeel panel element, and then followed by truss and diagonal chord around vierendeel panel element, while the critical condition showed still at life safety level.
\end{abstract}

Keywords: Reduced Beam Section, vierendeel, Staggered Truss Frame, Special Moment Resisting Frame, ductility, nonlinear pushover analysis.

\begin{abstract}
Abstrak: Studi ini bertujuan untuk mengetahui pengaruh Reduced Beam Section (RBS) pada elemen vierendeel panel terhadap perilaku inelastik gedung STF berdasarkan analisa beban gempa. Sistem STF diaplikasikan sebagai gedung perkantoran dengan variasi 4, 6, dan 10 lantai. Sistem struktur yang digunakan yaitu sistem Special Moment Resisting Frame $(S M R F)$ pada arah longitudinal (B-T), dan sistem STF pada arah transversal (U-S). Analisa yang digunakan yaitu analisa nonlinier beban dorong (pushover). Dengan adanya RBS menunjukkan bahwa dengan bertambahnya jumlah lantai, nilai daktilitas struktur meningkat di kedua arah, akan tetapi arah U-S mempunyai nilai yang lebih besar dari arah B-T. Energi disipasi yang mampu diserap juga meningkat terutama pada arah U-S. Mekanisme keruntuhan struktur terjadi pelelehan pertama kali pada vierendeel panel, kemudian diikuti oleh truss dan diagonal chord di sekitar vierendeel panel dengan kondisi kritis masih pada tingkat life safety.
\end{abstract}

Kata Kunci: Reduced Beam Section, vierendeel, Staggered Truss Frame, Special Moment Resisting Frame, daktilitas, analisa nonlinier pushover.

\section{PENDAHULUAN}

Sistem staggered truss framing terdiri atas rangkaian rangka batang tersusun (truss), dengan ketinggian truss setinggi tingkat yang membentang keseluruhan lebar antara dua baris kolom eksterior dan diatur dalam pola bergantian (staggered) pada garis kolom yang berdekatan [1]. Konsep sistem STF dapat dilihat pada Gambar 1. Pada sistem STF membutuhkan elemen Truss yang menyediakan suatu bukaan ditengah bentang (vierendeel panel) yang berfungsi sebagai koridor dimana perbandingan panjang vierendeel panel dengan jarak antar truss vertikal memiliki peranan penting dalam proses plastifikasi yang mempengaruhi mekanisme keruntuhan pada sistem STF [2]. Berdasarkan hasil evaluasi kinerja juga diketahui bahwa model STF1, STF2 dan STF3 (rasio $0.842,1.081$ dan 1.333) memberikan tingkat kinerja yang

aStudent in the Department of Civil Engineering, Sepuluh Nopember Institute of Technology (ITS), ITS Campus, Sukolilo, Surabaya 60111, Indonesia. Email: farid.civileng@gmail.com

${ }^{\mathrm{b}}$ Lecturer in the Department of Civil Engineering, Sepuluh Nopember Institute of Technology (ITS), ITS Campus, Sukolilo, Surabaya 60111, Indonesia. Email: endah@ce.its.ac.id

${ }^{\mathrm{c}}$ Lecturer in the Department of Civil Engineering, Sepuluh Nopember Institute of Technology (ITS), ITS Campus, Sukolilo, Surabaya 60111, Indonesia. Email: data@ce.its.ac.id

Note. The manuscript for this paper was submitted for review and possible publication on January 02, 2017. This paper is part of the ITS Journal of Civil Engineering, Vol. 32, No. 2, November 2017. (C) ITS Journal of Civil Engineering, ISSN 2579-9029/2017. kurang baik diterapkan karena pada kondisi kritisnya telah berada pada tingkat collapse prevention maupun collapse. Sementara pada model STF4 dan STF5 (rasio 1.6 dan 1.882) telah menunjukan kinerja seperti yang diharapkan karena pada kondisi kritis gedung masih berada pada tingka life safety [2]. Konsep dasar RBS adalah mereduksi bagian dari balok baja di dekat sambungan balok-kolom yang dimaksudkan untuk menimbulkan sendi plastis di daerah RBS. Konsep ini disebut dengan konsep dogbone yang pertama kali dikembangkan oleh Plumier, 1990 [3]. RBS dapat meningkatkan elastis drift sebesar 9\% dengan pengurangan lebar sayap sebesar $50 \%$, dengan interpolasi linier untuk nilai yang lebih rendah pada pengurangan lebar sayap [3]. Sehingga tujuan dalam studi ini adalah untuk mengetahui pengaruh RBS pada vierendeel panel terhadap daktilitas struktur yang terjadi.

\section{METODOLOGI}

Metodologi pada penelitian ini meliputi analisa linier dan nonlinier.

\section{Analisa Respons Spektrum}

Beban gempa yang digunakan adalah data gempa yang terjadi sesuai dengan lokasi gedung berada. Pada studi ini lokasi gedung direncanakan di Kota Yogyakarta dengan asumsi tanah berjenis keras. Berdasarkan peraturan [7] didapatkan percepatan batuan dasar untuk kota Yogyakarta adalah $\mathrm{S}_{\mathrm{s}}=1.212$ dan $\mathrm{S}_{1}=0.444$, sedangkan 


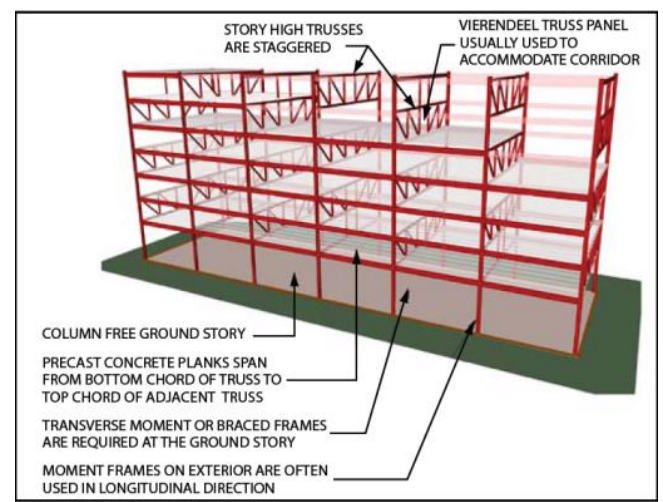

Gambar 1. Konsep Konfigurasi Sistem Staggerede Truss Framing [2]

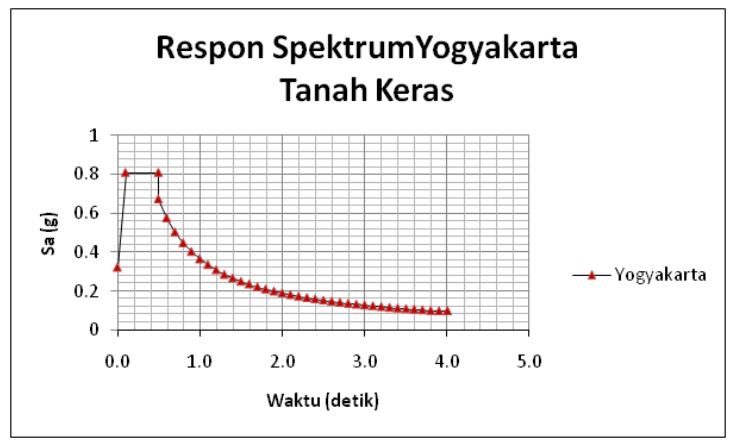

Gambar 2. Respon Spektrum Desain Kota Yogyakarta sesuai SNI 1726-2012

untuk klasifikasi situs tergolong kelas situs SC. Dari data dan klasifikasi tersebut, berdasarkan perhitungan pada peraturan [7] didapatkan grafik respon spektrum yang terlihat pada Gambar 2.

\section{Desain Reduced Beam Section}

RBS didesain untuk menentukan letak dan dimensi sendi plastis pada elemen yang direncanakan. Dengan letak dan dimensi sendi plastis ini, dapat diprediksikan perilaku elemen yang direncanakan mengalami leleh pertama seperti yang diharapkan. Pada studi ini elemen yang didesain RBS adalah elemen vierendeel panel. Selain itu untuk didapatkan hasil yang lebih ideal RBS juga didesain pada elemen spandrel beam.

RBS yang digunakan pada adalah RBS jenis radius cut, yaitu dengan memotong kedua sisi dari sayap elemen dengan sudut membentuk garis kurva sebesar 50\%. RBS tersebut didesain pada kedua ujung dari elemen vierendeel panel dengan jarak yang sudah ditentukan oleh perhitungan sesuai pada [3]. Gambar 3 menjelaskan letak dan dimensi RBS pada vierendeel panel.

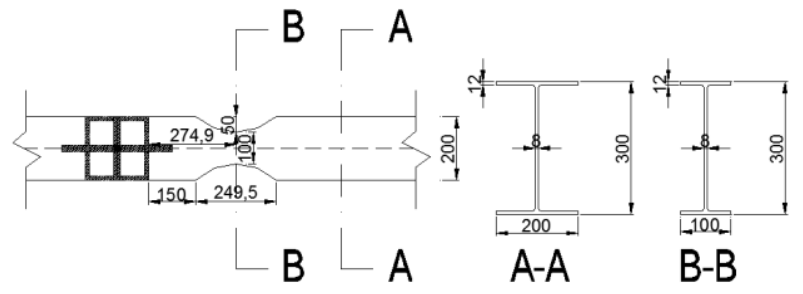

Gambar 3. Geometri RBS Bentuk Radius Cut

Dengan adanya RBS pada vierendeel panel, kapasitas penampang yang ditentukan oleh nilai kurvatur dan momen kurvatur mengalami penurunan atau pengurangan. Nilai kurvatur dan momen kurvatur tersebut mempunyai peranan penting dalam menentukan mekanisme keruntuhan struktur. Seperti terlihat pada Gambar 4, dimana nilai kurvatur dan momen kurvatur arah transversal (menyesuaikan posisi elemen vierendeel panel pada struktur STF) didapatkan dengan program bantu [11].

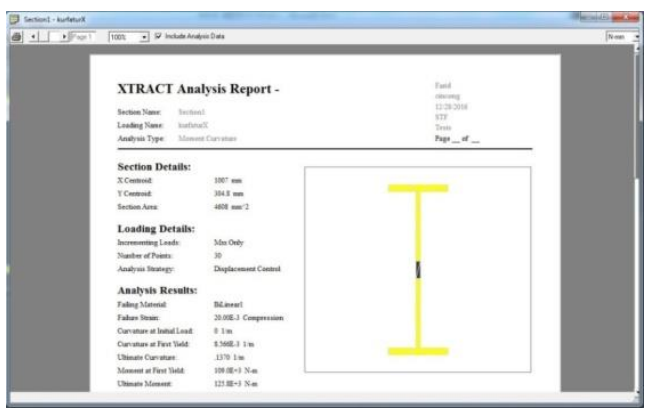

Gambar 4. Output EXTRACT

Nilai kurvatur dan momen kurvatur tersebut dimasukkan ke dalam desain hinges properties pada pemodelan pada saat analisa nonlinear pushover, dimana tipe hinges properties pada elemen vierendeel panel yaitu tipe PM3. Sedangkan hinges properties pada elemen spandrel beam diasumsikan sebagai M3. Gambar 5 dan 6 menunjukkan desain hinges properties pada elemen vierendeel panel dan elemen spandrel beam.

\section{Analisa Nonlinier Pushover}

Evaluasi kinerja struktur dapat dilakukan dengan empat analisis yang berbeda, yaitu secara statis linier, dinamis linier, statis nonlonier dan dinamis nonlinier [4]. penggunaan analisis nonlinier statik pushover untuk bangunan yang didominasi oleh mode pertama memberikan hasil yang konservatif baik perpindahan lateral maupun gaya dalam yang dari sisi pandang 


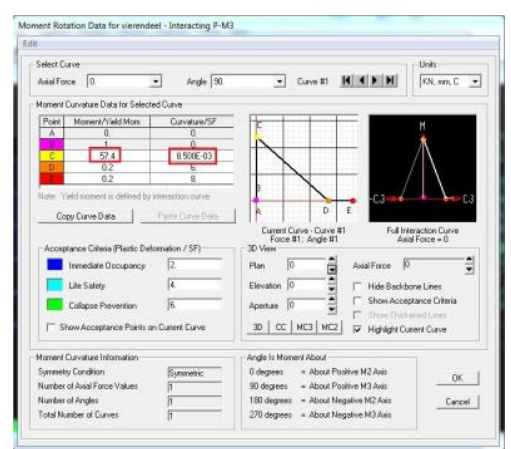

Gambar 5. Geometri RBS Bentuk Radius Cut

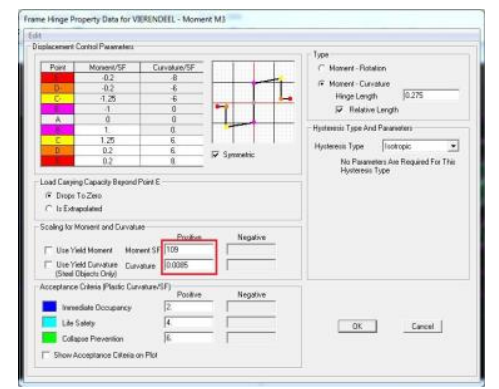

Gambar 6. Output EXTRACT

perencanaan dapat diterima [4]. Analisis nonlinier statik pushover dilakukan dengan memberikan suatu pola beban lateral statik pada struktur, yang kemudian secara bertahap ditingkatkan dengan faktor pengali sampai satu target perpindahan lateral dari suatu titik acuan tercapai. Biasanya titik tersebut adalah titik pada atap, atau lebih tepat lagi adalah pusat massa atap. Analisis pushover menghasilkan kurva pushover, kurva yang menggambarkan hubungan antara gaya geser dasar versus perpindahan titik acuan pada atap. Pada proses pushover, struktur didorong sampai mengalami leleh di satu atau lebih lokasi di struktur tersebut. Kurva kapasitas akan memperlihatkan suatu kondisi linier sebelum mencapai kondisi leleh dan selanjutnya berperilaku nonlinier. Tujuan analisis pushover adalah untuk memperkirakan gaya maksimum dan deformasi yang terjadi serta untuk memperoleh informasi bagian mana saja yang kritis [2]. Pada analisa nonlinier pushover dibutuhkan letak sendi plastis pada elemen-elemen struktur seperti balok, kolom, dan bracing. Pada elemen balok dan kolom sendi plastis direncanakan pada ujung-ujung elemen dengan jarak $10 \%$ dari panjang elemen pada ujung satu dan $90 \%$ dari panjang elemen pada ujung lainnya. Pada elemen bracing sendi plastis diletakkan pada tengah elemen. Sedangkan pada elemen vierendeel panel sendi plastis diletakkan pada jarak sesuai dengan desain RBS yang terlihat pada Gambar 3. Tipe sendi plastis pada studi ini berdasarkan peraturan [6] dan dengan program bantu [10].

\section{Tingkat Kinerja Bangunan}

Adapun penetapan tingkat kinerja suatu bangunan dapat didasarkan atas aturan tingkat keselamatan yang diberikan kepada penghuni gedung selama dan sesudah terjadi gempa serta biaya terhadap kerusakan gedung pasca gempa. Dengan kata lain tingkat kinerja merupakan suatu kerusakan maksimum yang masih diijinkan sesuai dengan tingkat kepentingan dan pertimbangan ekonomis dari pemilik bangunan yang akan dibangun [2]. Peraturan
[6] mengatur tingkat kinerja suatu bangunan sebagai berikut:

1. Operasional

Tak ada kerusakan berarti pada struktur dan nonstruktur, bangunan tetap berfungsi.

2. Immediate Occupancy (IO)

Tidak ada kerusakan yang berarti pada komponen struktural dimana kekuatan dan kekakuannya kirakira hampir sama dengan kondisi sebelum gempa. Komponen non-struktur masih berada ditempatnya dan sebagian besar masih berfungsi jika utilitasnya tersedia. Bangunan dapat tetap berfungsi dan tidak terganggu dengan masalah perbaikan.

3. Life Safety (LS)

Terjadi kerusakan komponen struktur, kekakuan berkurang, tetapi masih mempunyai ambang yang cukup terhadap keruntuhan. Komponen non-struktur masih ada tapi tidak berfungsi. Dapat dipakai lagi jika sudah dlakukan perbaikan.

4. Collapse Prevention (CP)

Kerusakan yang berarti pada komponen struktur dan non struktur. Kekuatan struktur dan kekakuannya berkurang banyak, hampir runtuh. Kecelakaan akibat kejatuhan material bangunan yang rusak sangat mungkin terjadi.

\section{Pemodelan STF}

Pada studi ini terdapat tiga model yang direncanakan yaitu model STF1 (4 lantai), STF2 (6 lantai), STF3 (10 lantai). Dimana rencana desain struktur gedung pada semua model STF adalah tipikal. Seperti dapat dilihat pada Gambar 7 yang menjelaskan rencana desain model STF1, yang secara keseluruhan sama dengan kedua model lainnya. Adapun data teknis ketiga model STF adalah sebagai beikut;

- Fungsi bangunan : Perkantoran

- Faktor keutamaan : 1

- Lebar bangunan : 18 meter [5] 
- Panjang bangunan : 7 x 6 meter $=42$ meter

- Tinggi bangunan : STF1(4 lantai $=4 \times 3,5 \mathrm{~m}=14 \mathrm{~m})$ STF2 (6 lantai $=6 \times 3,5 \mathrm{~m}=21 \mathrm{~m})$ STF3(10 lantai $=10 \times 3,5 \mathrm{~m}=35 \mathrm{~m}$ )

- $\quad$ Mutu baja profil : BJ41(fy=250MPa; fu=410MPa)

- Mutu beton : $\mathrm{fc}^{\prime}=35 \mathrm{MPa}$

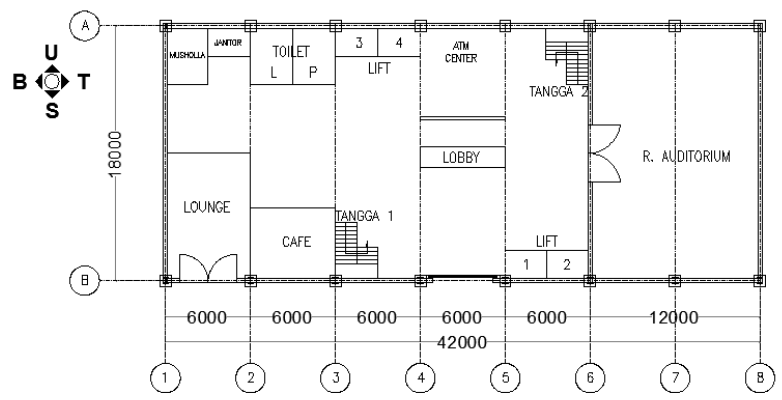

(a). Lantai Dasar

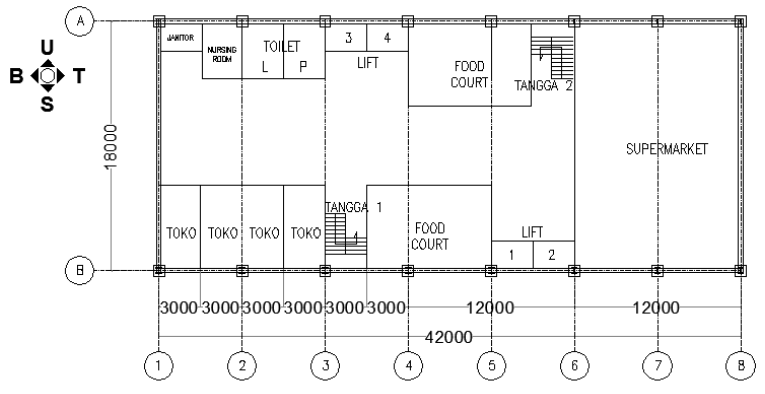

(b). Lantai 2 dan Seterusnya

Gambar 7. Denah Rencana Tipikal STF1, STF2, STF3

Profil elemen-elemen gedung STF yang digunakan dijelaskan pada Tabel 1. Semua elemen yang digunakan telah dihitung berdasarkan pembebanan [8] dan analisa penampang sesuai dengan [9]. Tampak 3D model gedung STF1 dapat dilihat pada Gambar 8, sedangkan pada Gambar 9 merupakan tampak 2D gedung STF1. Seperti terlihat pada Gambar 9, terdapat dua arah sistem struktur, yaitu arah B-T merupakan arah longitudinal dengan sistem struktur SMRF, sedangkan arah U-S merupakan arah transversal dengan sistem struktur STF. Dimana konfigurasi elemen struktur pada ketiga model STF adalah sama. Faktor reduksi gempa $(\mathrm{R})$ yang digunakan untuk arah B-T adalah 8, sedangkan untuk arah U-S adalah 7. Perbandingan antara panjang vierendeel panel dengan jarak antar vertical truss yang digunakan pada semua model STF adalah sama, yaitu sebesar 1,6.

Tabel 1 Konfigurasi Komponen Struktur STF

\begin{tabular}{|c|c|}
\hline Komponen Struktur & Tipe Profil \\
\hline Column & WF $400 \times 400 \times 30 \times 50$ \\
\hline Spandrel Beam Atap & WF $600 \times 200 \times 11 \times 17$ \\
\hline Spandrel Beam Lantai & WF $600 \times 300 \times 12 \times 20$ \\
\hline Truss Chord & WF $300 \times 200 \times 8 \times 12$ \\
\hline Vierendeel Panel & WF 300x200x8x12 \\
\hline Truss Diagonal & HSS $200 \times 200 \times 12$ \\
\hline Truss Hanger & HSS $200 \times 200 \times 12$ \\
\hline Truss Knee Brace & HSS $200 \times 200 \times 12$ \\
\hline Truss Post & HSS $200 \times 200 \times 12$ \\
\hline Truss Vertical & HSS $200 \times 200 \times 12$ \\
\hline
\end{tabular}

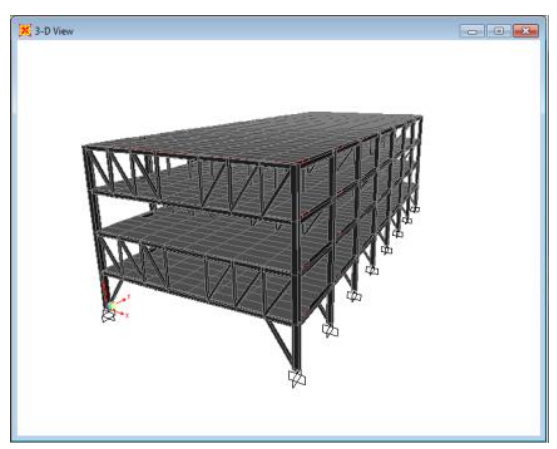

Gambar 8. Pemodelan 3D STF1

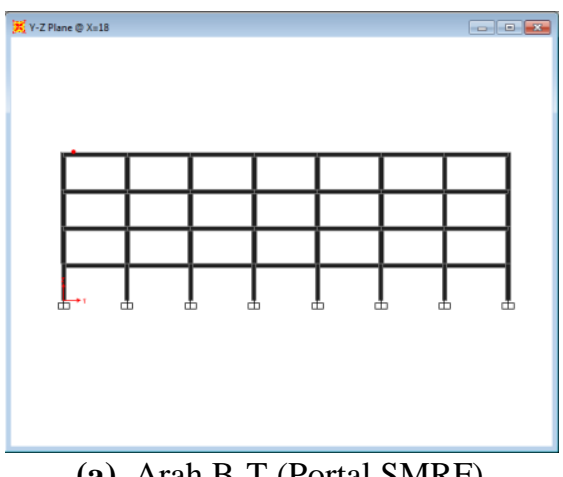

(a). Arah B-T (Portal SMRF)

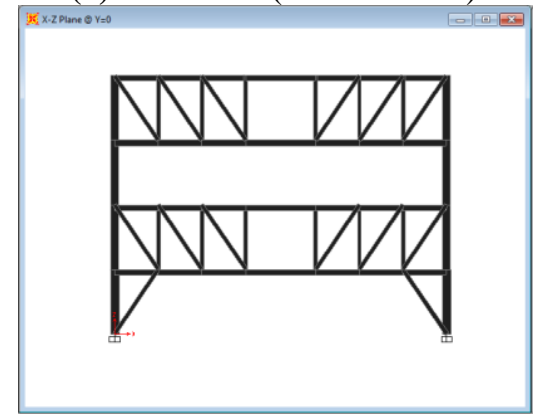

(b). Arah U-S (Portal STF)

Gambar 9. Pemodelan 2D STF1

\section{HASIL DAN PEMBAHASAN ANALISA LINEAR}

Analisa linear merupakan analisa gempa respon spektrum dan gempa statik ekivalen. Kedua analisa tersebut digunakan untuk mengetahui perilaku total drift dan inter story drift dimana terdapat perbandingan antara semua model STF yang cukup signifikan. Pada Gambar 10 menjelaskan perbandingan nilai total drift antara ketiga model STF, dimana Gambar 10 (a) adalah untuk arah B-T (portal SMRF) dan Gambar 10 (b) adalah untuk arah U-S (portal STF). Terlihat bahwa untuk arah B-T nilai total drift akibat gempa statik ekivalen lebih besar dari gempa respon spektrum pada ketiga model. begitu juga untuk arah U-S terjadi perilaku yang sama. Terlihat juga bahwa semakin banyak jumlah lantai nilai total drift pada ketiga model untuk kedua arah baik akibat gempa statik ekivalen maupun gempa respon spektrum juga semakin meningkat. Secara keseluruhan dapat dilihat bahwa niai total drift pada arah U-S lebih kecil dari arah B-T, sehingga dapat disimpulkan bahwa portal STF lebih kaku dari portal SMRF. Fenomena perilaku yang sama pada perbandingan inter story drift pada kedua arah pada semua model STF, seperti yang terlihat pada Gambar 11. 


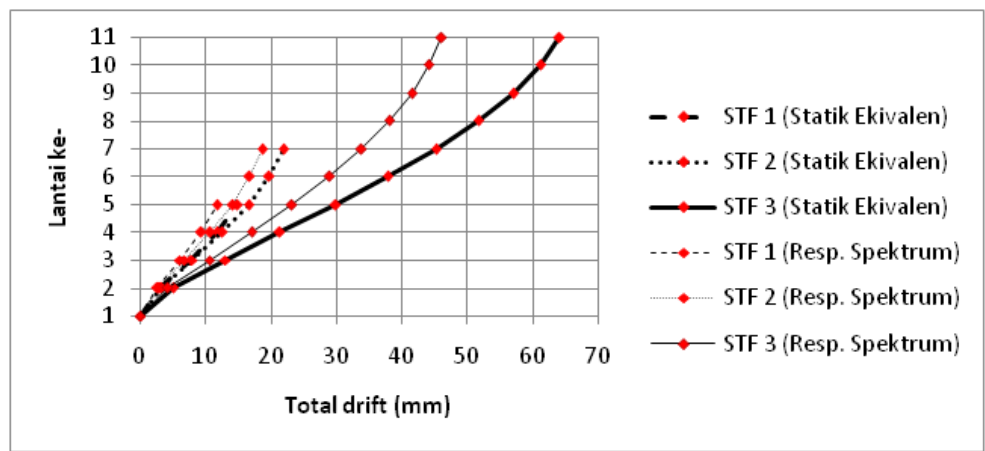

(a). Arah B-T (Portal SMRF)

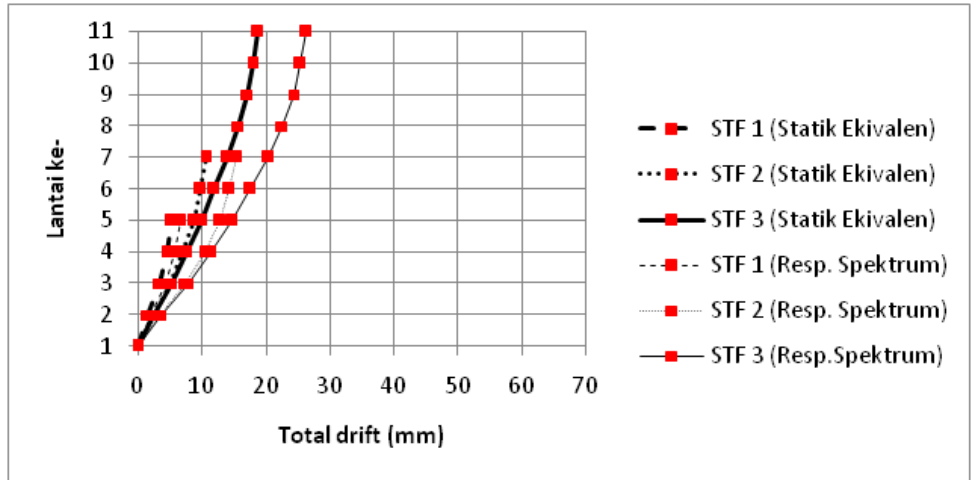

(b). Arah U-S (Portal STF)

Gambar 10 Grafik Perbandingan Total Drift untuk Arah B-T dan U-S

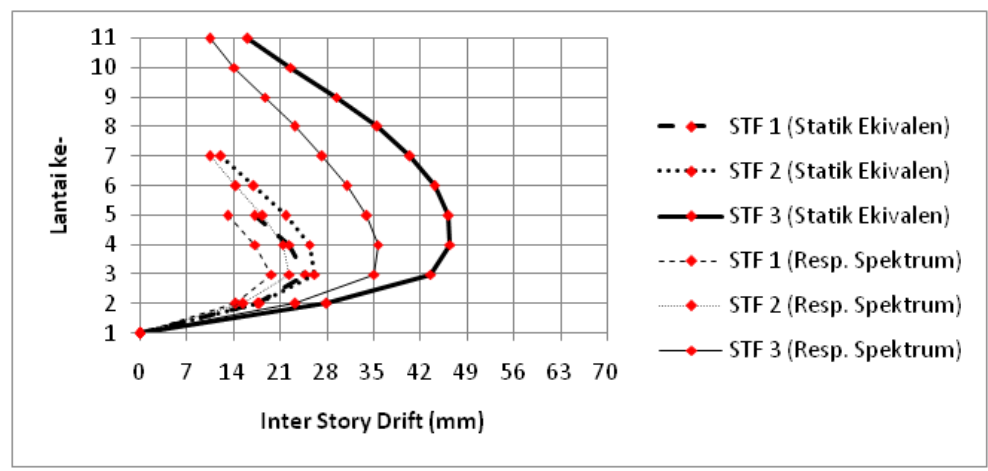

(a). Arah B-T (Portal SMRF)

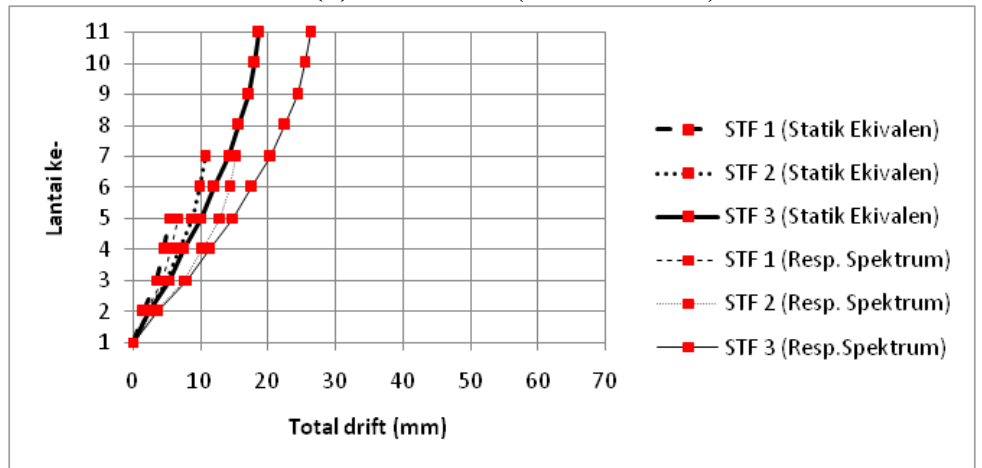

(b). Arah U-S (Portal STF)

Gambar 11 Grafik Perbandingan Inter Story Drift untuk Arah B-T dan U-S

Tabel 2. Perbandingan Hasil Analisa Linear

\begin{tabular}{ccccccc}
\hline \multirow{2}{*}{ Model } & \multicolumn{2}{c}{ Periode Massa } & \multicolumn{2}{c}{ Partisipasi Massa } & \multicolumn{2}{c}{ Gaya Dasar } \\
\cline { 2 - 7 } & Arah B-T & Arah U-S & Arah B-T & Arah U-S & Arah B-T & Arah U-S \\
\hline STF1 & 0.545 & 0.38 & 0.988 & 0.906 & 1280.69 & 1744.95 \\
STF2 & 0.78 & 0.561 & 0.974 & 0.918 & 1381.076 & 2131.437 \\
STF3 & 1.292 & 0.905 & 0.981 & 0.932 & 1491.627 & 2196.833 \\
\hline
\end{tabular}


Dari analisa linear juga didapatkan kontrol simpangan maksimum dari semua nilai total drift pada kedua arah pada ketiga model masih di bawah nilai simpangan ijin, yaitu $70 \mathrm{~mm}$. Didapatkan pula kontrol partisipasi massa yang semuanya di atas $90 \%$, serta gaya dasar dinamis struktur yang di bawah $85 \%$ gaya dasar statik ekivalen. Didapatkan pula nilai periode massa, yang menunjukkan bahwa semakin banyak jumlah lantai semakin besar nilai periode massanya, dan periode massa arah U-S lebih kecil dari arah B-T, yang artinya portal STF lebih kaku dari SMRF. Seperti yang dijelaskan pada Tabel 2.

\section{HASIL DAN PEMBAHASAN ANALISA NONLINEAR PUSHOVER}

Berdasarkan hasil analisa statik nonlinier pushover, didapatkan perbandingan kurva kapasitas struktur untuk arah B-T (portal SMRF) seperti ditampilkan pada Gambar 12. Terlihat bahwa semakin banyak jumlah lantai semakin besar pula perpindahan lantai atap saat runtuh $(\delta \mathrm{u})$ yang terjadi. Akan tetapi semakin banyak jumlah lantai mengakibatkan semakin kecil gaya dasar yang mampu diterima oleh struktur. Hal yang sama tampak pada hasil perbandingan kurva kapasitas struktur untuk arah U-S (portal STF) seperti terlihat pada Gambar 13. Terlihat bahwa semakin banyak jumlah lantai semakin besar pula perpindahan lantai atap saat runtuh $(\delta u)$ yang terjadi. Begitu juga dengan gaya dasar yang mampu diterima oleh struktur mengalami penurunan seiring dengan bertambahnya jumlah lantai. Hal ini menunjukkan struktur dengan jumlah lantai yang lebih kecil lebih kaku.

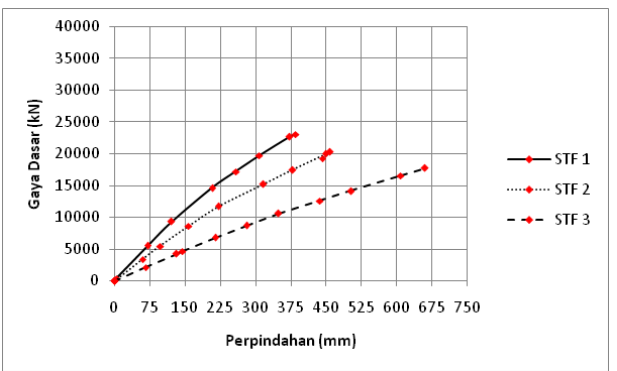

Gambar 12 Grafik Perbandingan Kurva Kapasitas Struktur untuk Arah B-T (Portal SMRF)

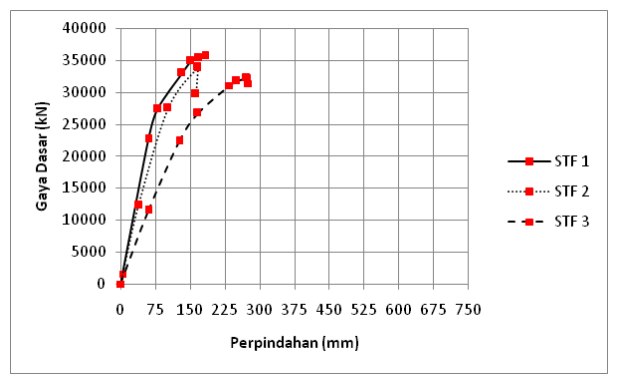

Gambar 13 Grafik Perbandingan Kurva Kapasitas Struktur untuk Arah U-S (Portal STF)

Pada Gambar 14 terlihat bahwa daktilitas struktur di kedua arah (arah B-T dan U-S) mengalami peningkatan seiring dengan penambahan jumlah lantai. Selain itu terlihat juga bahwa nilai daktilitas struktur SMRF (arah B-T) lebih kecil dari struktur STF (arah U-S). Hal ini menunjukkan bahwa struktur STF (arah U-S) mempunyai perilaku yang lebih baik dari struktur SMRF (arah B-T).

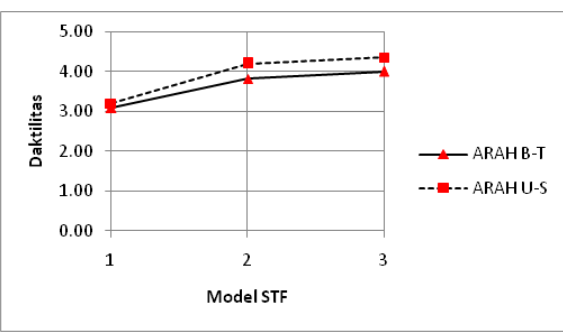

Gambar 14 Grafik Perbandingan Daktilitas Tiap Model Gedung STF

Berdasarkan hasil evaluasi kinerja pada saat gempa rencana terjadi, gedung STF1, STF2, dan STF 3 pada kedua arahnya berada dalam kondisi immediate occupancy dan life safety yaitu kondisi ideal yang diharapkan, seperti yang terjelaskan pada Tabel 3 dan Tabel 4.

Pada Gambar 15 menunjukkan mekanisme keruntuhan yang terjadi pada model STF2, dimana diketahui bahwa pada arah B-T pelelehan pertama terjadi pada ujung elemen spandrel beam pada di lantai bawah yang kemudian diikuti oleh pelelehan pada elemen spandrel beam di lantai lainnya, sampai dengan terjadi plastifikasi pada ujung kolom lantai bawah. Pada arah U-S pelelehan pertama terjadi pertama kali pada elemen vierendeel pada lantai dasar, kemudian diikuti pada elemen vierendeel pada lanta- lantai selanjutnya, baru diikuti pelelehan pada elemen-elemen truss chord di area vierendeel dan knee brace pada lantai dasar. Hal ini relatif terjadi juga pada semua model STF yang lainnya. Gambar 15 (a) menunjukkan mekanisme keruntuhan arah B-T pada saat pertama leleh, dan Gambar 15 (b) pada saat runtuh pada model STF2. Sedangkan pada Gambar 15 (c) dan (d) menunjukkan mekanisme keruntuhan pada arah U-S pada saat pertama leleh dan pada saat runtuh pada model STF2. Sementara itu pada Tabel 5 dan Tabel 6 diketahui perbandingan kapasitas struktur STF tanpa dan dengan RBS pada elemen vierendeel. Dari kedua tabel tersebut dapat dilihat bahwa terjadi penurunan daktilitas pada arah B-T, tetapi terjadi peningkatan pada arah U-S. Diketahui juga bahwa nilai gaya dasar yang mampu diterima struktur STF (arah U-S) dengan RBS pada elemen vierendeel lebih besar dari struktur STF (arah U-S) tanpa RBS pada elemen vierendeel. Hal ini menunjukkan bahwa ada pengaruh dari desain RBS pada elemen vierendeel mampu menerima gaya lateral yang lebih besar pada struktur STF sehingga perilaku struktur STF lebih daktail daripada stuktur SMRF.

Terlihat juga pada Gambar 16 dimana perilaku yang terjadi antara model STF2 tanpa adanya RBS dan dengan adanya RBS. Terlihat bahwa nilai perpindahan pada kedua arah (arah B-T dan U-S) relatif naik dengan adanya RBS. Gaya dasar yang terjadi pada arah U-S dengan adanya RBS meningkat drastis dibandingkan dengan tanpa adanya RBS. Sehingga dari tren grafik yang terlihat struktur STF dengan adanya RBS cenderung mampu menerima gaya lateral yang lebih besar. Hal ini menunjukkan bahwa dengan adanya RBS pada elemen vierendeel panel mempunyai pengaruh yang cukup signifikan pada perilaku inelastik struktur staggered truss frame. 
Tabel 3. Perbandingan Perhitungan Daktilitas Arah B-T

\begin{tabular}{ccccccc}
\hline Model & $\delta \mathrm{y}(\mathrm{mm})$ & $\mathrm{Vy}(\mathrm{kN})$ & $\delta \mathrm{u}(\mathrm{mm})$ & $\mathrm{Vu}(\mathrm{kN})$ & $\mu \Delta$ & Performance Level \\
\hline STF1 & 124.7 & 12904.1 & 385.063 & 23068.6 & 3.088 & Immediate Occupancy \\
STF2 & 119.7 & 6767.5 & 457.671 & 20312.6 & 3.823 & Immediate Occupancy \\
STF3 & 164.7 & 5357.5 & 659.96 & 17719.7 & 4.007 & Immediate Occupancy \\
\hline
\end{tabular}

Tabel 4. Perbandingan Perhitungan Daktilitas Arah U-S

\begin{tabular}{ccccccc}
\hline Model & $\delta \mathrm{y}(\mathrm{mm})$ & $\mathrm{Vy}(\mathrm{kN})$ & $\delta \mathrm{u}(\mathrm{mm})$ & $\mathrm{Vu}(\mathrm{kN})$ & $\mu \Delta$ & Performance Level \\
\hline STF1 & 56.9 & 21600.1 & 182.262 & 35752.4 & 3.203 & Immediate Occupancy \\
STF2 & 39.6 & 12590 & 166.508 & 33959.8 & 4.205 & Life Safety \\
STF3 & 62.5 & 12140 & 272.738 & 32330.2 & 4.364 & Immediate Occupancy \\
\hline
\end{tabular}

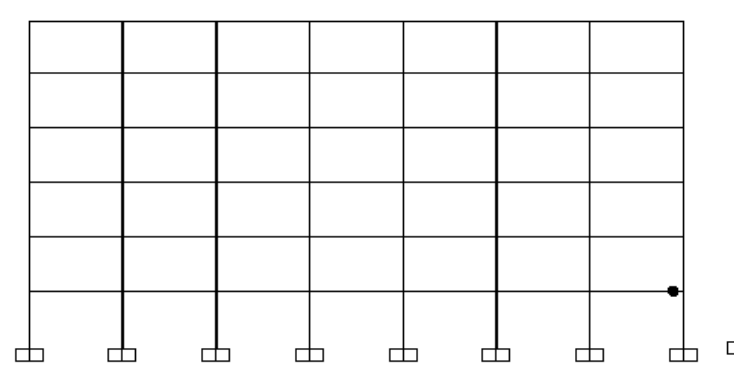

(a) Step 2

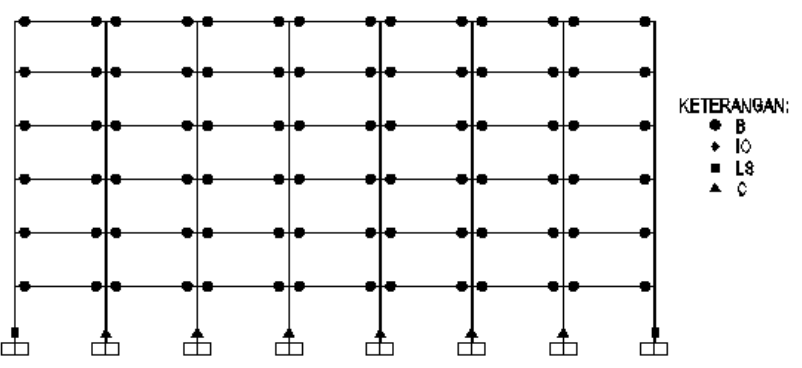

(b) Step 4

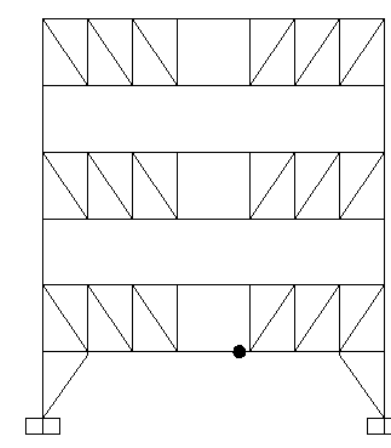

(a) Step 1

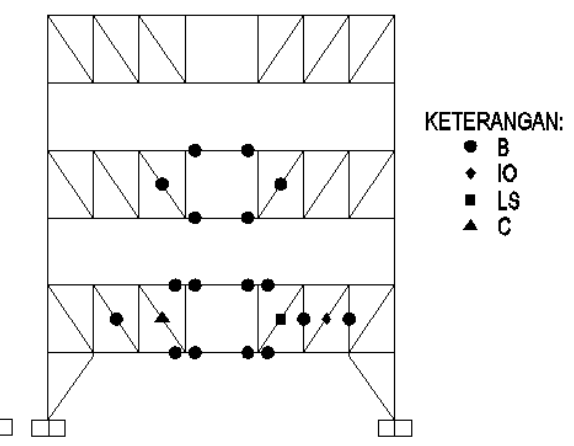

(b) Step 4

Gambar 15 Mekanisme Keruntuhan Gedung STF2 Arah B-T dan U-S

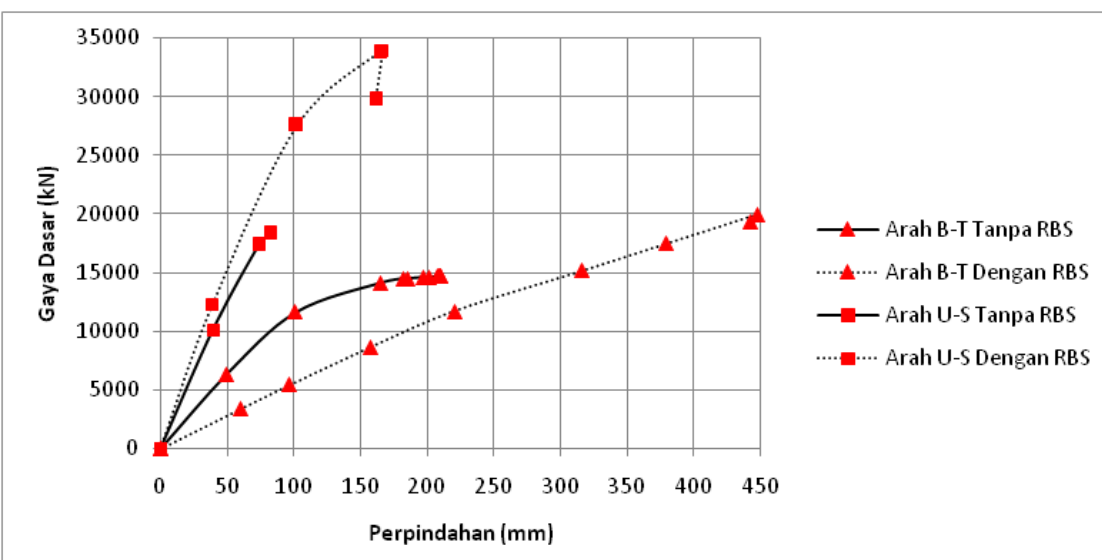

Gambar 16 Grafik Perbandingan Gaya Dasar dan Perpindahan STF 2 Tanpa dan Dengan RBS 
Tabel 5. Perhitungan Daktilitas Struktur Gedung STF2 Tanpa RBS

\begin{tabular}{cccccc}
\hline Arah & $\boldsymbol{\delta y}(\mathbf{m m})$ & $\mathbf{V y}(\mathbf{k N})$ & $\boldsymbol{\delta u}(\mathbf{m m})$ & $\mathbf{V u}(\mathbf{k N})$ & $\boldsymbol{\mu} \Delta$ \\
\hline B-T & 49.716 & 6358.658 & 210.245 & 14670.29 & 4.229 \\
U-S & 39.539 & 10132.22 & 82.349 & 18331.36 & 2.083 \\
\hline
\end{tabular}

Tabel 6. Perhitungan Daktilitas Struktur Gedung STF2 Dengan RBS

\begin{tabular}{cccccc}
\hline Arah & $\boldsymbol{\delta y}(\mathbf{m m})$ & $\mathbf{V y}(\mathbf{k N})$ & $\boldsymbol{\delta u}(\mathbf{m m})$ & $\mathbf{V u}(\mathbf{k N})$ & $\boldsymbol{\mu} \Delta$ \\
\hline B-T & 119.7 & 6767.5 & 457.671 & 20312.6 & 3.823 \\
U-S & 39.6 & 12590 & 166.508 & 33959.8 & 4.205 \\
\hline
\end{tabular}

\section{KESIMPULAN}

Dari analisa dan pembahasan dalam studi ini didapatkan beberapa kesimpuan sebagai berikut;

1. Dengan bertambahnya jumlah lantai gedung staggered truss framing maka bertambah pula nilai total drift dan inter story drift pada analisa statik ekivalen maupun respon spektrum. Secara keseluruhan nilai total drift dan inter story drift dengan analisa statik ekivalen lebih besar dari analisa respon spektrum kecuali pada model STF 1 (jumlah lantai terkecil). nilai total drift dan inter story drift untuk arah U-S (STF) lebih kecil dari arah B-T (SMRF), sehingga disimpulkan model STF lebih kaku.

2. Secara umum, mekanisme keruntuhan dari sistem staggered truss framing ini akan mengalami pelelehan pertama kali pada elemen spandrel beam (arah B-T) dan elemen vierendeel panel (arah U-S) kemudian diikuti pelelehan pada elemen truss chord serta diagonal chord yang berada disekitar vierendeel panel tersebut. Dengan demikian maka vierendeel panel dan elemen struktur disekitarnya, memiliki peranan penting dalam proses plastifikasi dari sistem struktur staggered truss framing. Berdasarkan hasil evaluasi kinerja juga diketahui bahwa model STF1, STF2 dan STF3 (4, 6 dan 10 lantai) memberikan tingkat kinerja yang cukup baik diterapkan karena pada kondisi kritisnya masih berada pada tingkat Immediate Occupancy dan Life Safety.

3. Dengan adanya modifikasi penampang atau metode Reduced Beam Section (RBS) menunjukkan peningkatan nilai daktilitas pada kedua arah walaupun kecil selisihnya. Terlihat juga bahwa nilai perpindahan pada kedua arah (arah B-T dan U-S) relatif naik. Gaya dasar yang terjadi pada arah U-S dengan adanya RBS meningkat drastis dibandingkan dengan tanpa adanya RBS. Sehingga dari tren grafik yang terlihat model STF dengan adanya RBS cenderung mampu menerima gaya lateral yang lebih besar. Hal ini menunjukkan bahwa ada pengaruh dari desain RBS pada elemen vierendeel, strukturSTF mampu menerima gaya lateral yang lebih besar. Sehingga bisa disimpulkan bahwa desain RBS pada elemen vierendeel mempunyai pengaruh yang cukup signifikan.

\section{DAFTAR PUSTAKA}

[1] Setiyarto, Y., Djoko., "Sistem Staggered Truss Frame Sebagai Alternatif Sistem Struktur Bentang Lebar pada Gedung Bertingkat," MajalahIlmiah UNIKOM, Vol.6, No.2, Bandung, 2002.

[2] Wahyuni, Endah, dan Tethool, Yoga, C. V., "Effect of Vierendeel Panel width and vertical Truss Spacing Ratio in Staggered Truss Framing System under Earthquake Loads," International Journal of Civil engineering, Indonesia, Vol. 13, No. 2, Transaction A: Civile Engineering, 2015.

[3] Juniazhar, R. P., "Studi Perbandingan Berbagai Jenis Sambungan Kaku dengan Menggunakan Balok Reduced Beam Section," Tugas Akhir S1 TeknikSipil ITS, 2012, pp. 7-17.

[4] Tethool, Yoga, C., V., "Perilaku Inelastik Sistem Stagered Truss Framing pada Gedung Bertingkat dengan Analisis Nonlinier Beban Dorong dan Riwayat Waktu," Tesis Program S2 bidang StrukturTeknikSipil ITS, 2014, pp. 12-13.

[5] AISC, 2002, Steel Design Guide Series 14 Staggered Truss Framing System, New York.

[6] ASCE. FEMA 356 - Prestandard and Comentary for the Seismic Rehabilitation of Buildings, Federal Emergency Management Agency, Washington DC, 2000

[7] Standar Nasional Indonesia, "Standar Perencanaan Ketahanan Gempa untuk Struktur Bangunan Gedung (SNI 1726-2012), Bandung, BSN, 2012.

[8] Standar Nasional Indonesia, "Beban Minimum untuk Perancangan Bangunan Gedung dan Struktur Lain (SNI 1727:2013), Bandung, BSN, 2013.

[9] Standar Nasional Indonesia, "Tata Cara Perencanaan Struktur Baja untuk Bangunan Gedung (SNI 031729:2002), Bandung, BSN, 2002.

[10] SAP2000 Manual, Computer and Structure Inc., Barkeley, California, USA, 2010.

[11] EXTRACT Manual, TRC and Chadwell, Charles. 2007 